\title{
The lexicon of the Conductor's gaze
}

\author{
Isabella Poggi \\ Dipartimento di Filosofia, Comunicazione e \\ Spettacolo \\ Università Roma Tre \\ isabella.poggi@uniroma3.it
}

\author{
Alessandro Ansani \\ Dipartimento di Filosofia, Comunicazione e \\ Spettacolo \\ Università Roma Tre \\ ale.ansani@stud.uniroma3.it
}

\begin{abstract}
This work presents two studies investigating the existence of a lexicon of gaze in conducting, and its possible different mastery in musicians and laypeople. An observational qualitative study singled out 17 items of gaze used by Conductors in music rehearsal and concert, conveying interactional, affective and musical meanings to musicians in the ensemble, and exploiting four semiotic devices: the Conductor may use the same gaze types as laypeople and with the same meaning (generic codified), or with meaning more specific of musical performance (specific codified), and directly or indirectly iconic gaze items. In a subsequent perceptual study, 8 of the gaze items singled out were submitted to 177 between musicians and naif subjects asking them to interpret their meanings through open and closed questions. Results show that some gaze items, especially those conveying intensity (piano, forte) and other technical indications (high note, attack) are fairly recognized; yet, no significant differences result between expert and naif subjects. Gaze constitutes a lexicon also in music performance and exploits the same semiotic devices as gaze in everyday life. ${ }^{2}$
\end{abstract}

\section{CCS CONCEPTS}

- Applied computing $\rightarrow$ Sound and music computing • Applied computing $\rightarrow$ Performing arts - Computing methodologies $\rightarrow$ Discourse, dialogue and pragmatics • Computing methodologies $\rightarrow$ Cognitive science • Theory of computation $\rightarrow$ Semantics and reasoning.

\footnotetext{
(c) 2018 Association for Computing Machinery. ACM acknowledges that this contribution was authored or co-authored by an employee, contractor or affiliate of a national government. As such, the Government retains a nonexclusive, royaltyfree right to publish or reproduce this article, or to allow others to do so, for Government purposes only.

MOCO, June 28-30, 2018, Genoa, Italy

(C) 2018 Association for Computing Machinery.

ACM ISBN 978-1-4503-6504-8/18/06...\$15.00

https://doi.org/10.1145/3212721.321281
}

\section{KEYWORDS}

Music performance, conductor, body lexicons, meanings of gaze

\section{ACM Reference format:}

Isabella Poggi, Alessandro Ansani. 2018. The lexicon of the Conductor's gaze. In Proceedings of MOCO'18: 5th International Conference on Movement and Computing (MOCO'18). ACM, New York, NY, USA, 8 pages. https://doi.org/10.1145/3212721.321281

\section{GAZE IN EVERYDAY INTERACTION AND IN MUSIC COMMUNICATION}

The investigation of body movements and its simulation in robots or virtual agents requires a previous in-depth analysis of how such movements are performed and perceived; further, when these movements have a semantic import, whether as communicative signals or as informative cues about internal states of the agent who is performing them, their implementation in artificial systems demands a careful investigation of the meanings they convey.

As acknowledged across centuries, from ancient rhetoric (Aristotle, Cicero, Quintilian [1]) through the first seminal work of Argyle and Cook [2], gaze has been acknowledged as a very relevant human body signal, fulfilling syntactic and expressive functions [3 - 4], regulating turn-taking and asking and giving backchannel [5], pointing, providing iconic information on physical and metaphorical properties, signaling performatives and discursive functions [6].

A field in which gaze is particularly relevant is the Conductor's communication, a multimodal and multifunctional behavior in which, during rehearsal and performance, gaze, gestures, face and posture, provide information about the Conductor's mental states, the ensemble's interactional management, and the sound to produce: who should sing or play, when, what semantic content to express by words and music, what melody, rhythm, tempo, timbre, intensity, expression, musical structure to produce and how [7]. 
The relevance of gaze in Conductors' communication is witnessed by musicians and musicologists, who cite the magnetic force of gaze of single Conductors: like Antonio Guarnieri (1880-1952), who used very inconspicuous, almost motionless gestures, but conducted by his sharp and penetrating gaze, that bewitched the orchestra. Due to lack of visual documents about this Conductor, we cannot say if the legend of his magnetic gaze only concerned his charismatic force inducing enthusiasm or self-confidence in musicians - or whether his eyes would specifically convey musical meanings to the orchestra. But what if this were the case? Could we find a lexicon of the Conductor's gaze, just like a lexicon of gaze can be written down for everyday communication [8]?

\section{LEXICONS OF THE BODY IN MUSIC MAKING}

The very idea that a gestural lexicon, let alone a gaze lexicon, are shared by conductors is not so widely accepted. Yet, the conductors' gestures have been studied in the musical domain especially concerning their rhythmical import [9 - 11]. Within gesture studies, the iconic and metaphorical aspects of the conductor's hand movements have been investigated [12 - 13], while [14] and [15] analyze them to construct conducting interfaces. [16] proposes that the conductor's body signals gesture, gaze, facial expression - can be considered as lexicons, i.e., steady and shared signal-meaning pairs that can be collected and analyzed to form a repertoire. After singling out, through observational qualitative analysis, the gestures of intensity asking for piano, forte, crescendo, diminuendo, [17 - 19] test their comprehensibility by expert and naïve subjects in an empirical study.

The lexicon of the pianist's head, face and trunk was also outlined [19]: during rehearsal and concert, a pianist performs communicative acts, including performatives of information, praise or incitation and propositional contents like "play faster", and expression or communication of cognitive states like concentration, or of felt and enacted emotions. The felt ones include "process" emotions, those occurring while playing, like anxiety about performance, and "outcome" emotions, like pleasure or dissatisfaction for the produced sound; the enacted ones include emotions simulated by the musician to impress them into the music played ("meaning oriented" emotion expressions) and those expressed to help perform the technical movements ("movement oriented": e.g. a frown of anger helps to mobilize energy for a loud sound). Finally, some body movements, or the manner they are performed, are of help for the musician's technical movements (e.g., a circular head movement may help perform an analogous circular hand movement) and may favor the production of any muical parameter: melody, rhythm, intensity, harmony.

In line with this body of research, this paper presents a qualitative observational study aimed at outlining a lexicon of gaze in orchestra and choir conduction, and a perceptual study aimed at testing if a subset of gaze items of this lexicon are actually understood by expert and naïve subjects.

\section{THE CONDUCTOR'S GAZE AS A MEANS FOR MUSICAL INDICATION}

Our hypothesis is that during rehearsal and concert the classical orchestra and choir conductors use gaze as an important communication system - a lexicon, that is, a systematic and shared list of signal-meaning pairs - to convey information and requests relevant for music making.

To test this hypothesis, we run a qualitative observational study on a corpus of video fragments from rehearsals and concerts. The corpus includes 99.43 minutes of musical performance by the amateur choir "Orazio Vecchi" of Rome, conducted by $\mathrm{M}^{\mathrm{o}}$ Alessandro Anniballi: 5 fragments from Gabriel Fauré's "Requiem" ( 2 in concert and 3 in rehearsal), 3 from Antonio Vivaldi's "Magnificat" (1 in concert and 2 in rehearsals), and 1 from Gioachino Rossini's "Petite Messe Solennelle" (1 concert fragment).

All fragments were analyzed according to the principles of [8]: any signal of any modality can be physically described in terms of its parameters (e.g., in gaze, eyes direction, eyelids aperture, eyebrow movements...); it may have both a literal meaning and a further "contextual" meaning that, though not explicitly stated, can be inferred in a specific context; and both the literal and the contextual meanings can be phrased into a verbal language.

For the analysis of the Conductor's gaze, the annotation scheme of Table 1 was adopted. Here, column 1 identifies the analyzed piece and the specific time under analysis; col.2, the words sung or the keys played at the same time of the analyzed gaze, while col. 3 describes parallel communication in other modalities (the conductor's words, gestures, head movements); in 4 the conductor's gaze is described in terms of its parameters; col.5 contains a verbal paraphrase of its literal meaning, and 6 one of its contextual meaning. On this basis the gaze item is classified, in col. 7, in terms of a semantic typology (as conveying a performative, an emotion, a cognitive state...), and in 8 as to its function of musical indication (intensity, attack...). Finally, col.9 specifies the semiotic device exploited by that gaze in communicating that meaning.

In Table 1, at line 1, Col. 4, the Conductor looks at tenors: in everyday communication this is a bare request for attention (col.5), but here it is a request to prepare to start (6): a gaze with a performative of request (7) aimed at indicating the attack (col.8), that is, who is to sing and when. This communicative signal, used in everyday life with a given meaning, is codified with a more specific meaning in the conductor's language: the semiotic device through which it is constructed is therefore "generic codified" (col.9). On line 2, the conductor raises his eyebrows very high (col.4), imitating an upward movement (5) aimed at requesting (7) a higher note (6): an indication of musical pitch (8) conveyed through a semiotic device of "direct iconicity" (9), imitation of an audible "raising" by a visible "raising". A device of "indirect iconicity" is exploited instead on line 3 where the conductor, while asking tenors to sing an $\mathrm{E}$ by extended index finger (col.2), sings it himself (3) and looks at them with frowning eyebrows (4) to mimic an expression of effort (5), thus asking 
them to strive maintaining that difficult note (6): here pitch indication (8) does not exploit the similarity between two movements (raising voice and raising eyebrow), but an expression of effort, that requests an effortful movement. Here gaze performs a sort of "motor induction": it requests the right pitch by evoking the technical movement (effort) necessary to produce it.

Line 4 shows another indirectly iconic gaze: the conductor frowns and squints his eyes (col.4) expressing anger (5); but the emotion of anger, mobilizing body energy, helps to sing aloud. This is then a request (6) to sing aloud, an indication of intensity
(8): the expression calls for the emotion, which in turn calls for energetic movement, hence loud sound.

Finally, while at line 6 the conductor's closed eyes (col.4) simply express a cognitive state (7) of concentration (8), at line 7 their combination with head shake and smile (col.3) can be interpreted as showing concentrated (col.5) to better feel the pleasure of music (6): an "outcome emotion" (7) which, when displayed to singers/players, has the motivating function (8) that a conductor, as the leader of a music ensemble, must fulfill.

In sect. 4 we overview the semiotic devices (col.9) exploited by the conductor's gaze items, and in Sect. 5 their meanings (columns 5-7), and musical functions (8).

Table 1. Annotation scheme of the Conductor's gaze

\begin{tabular}{|c|c|c|c|c|c|c|c|c|}
\hline $\begin{array}{l}1 . \\
\text { Fr. } \\
\text { TIME }\end{array}$ & $\begin{array}{l}2 . \\
\text { SINGI } \\
\text { NG OR } \\
\text { MUSIC }\end{array}$ & $\begin{array}{l}3 . \\
\text { VERBAL AND } \\
\text { OTHER } \\
\text { MODALITIES }\end{array}$ & $\begin{array}{l}4 . \\
\text { GAZE }\end{array}$ & $\begin{array}{l}5 . \\
\text { LITERAL } \\
\text { MEANING }\end{array}$ & $\begin{array}{l}6 . \\
\text { CONTEXTU } \\
\text { AL } \\
\text { MEANING }\end{array}$ & $\begin{array}{l}7 . \\
\text { TYPE OF } \\
\text { GAZE }\end{array}$ & $\begin{array}{l}8 . \\
\text { MUSIC } \\
\text { OR } \\
\text { INTERAC } \\
\text { TION } \\
\text { FUNCT. }\end{array}$ & $\begin{array}{l}9 . \\
\text { SEMIOTIC } \\
\text { DEVICE }\end{array}$ \\
\hline $\begin{array}{l}1 \\
\text { Req. PC } \\
0.02\end{array}$ & & & $\begin{array}{l}\text { Looks } \\
\text { rightward }\end{array}$ & $\begin{array}{l}\text { I request } \\
\text { your } \\
\text { attention }\end{array}$ & $\begin{array}{l}\text { Be ready to } \\
\text { start }\end{array}$ & Request & Attack & $\begin{array}{l}\text { SPECIFIC } \\
\text { CODIFIED }\end{array}$ \\
\hline $\begin{array}{l}2 \\
\text { Req.PS2 } \\
1.48\end{array}$ & $\begin{array}{l}\text { Ré- } \\
\text { qui- } \\
\text { em }\end{array}$ & & $\begin{array}{l}\text { Raises } \\
\text { eyebrows } \\
\text { very high }\end{array}$ & $\begin{array}{l}\text { I imitate a } \\
\text { raising }\end{array}$ & $\begin{array}{l}\text { Start with } \\
\text { the high } \\
\text { note }\end{array}$ & Request & Pitch & $\begin{array}{l}\text { DIRECT } \\
\text { ICONIC }\end{array}$ \\
\hline $\begin{array}{l}3 \\
\text { Req.PC } \\
2.44\end{array}$ & $\begin{array}{l}\text { Piano: } \\
\text { E C }\end{array}$ & $\begin{array}{l}\text { He sings } \\
\text { "mii" (E) } \\
\text { upright index } \\
\text { finger points } \\
\text { to tenors }\end{array}$ & $\begin{array}{l}\text { Frowns, } \\
\text { looks at } \\
\text { tenors }\end{array}$ & I strive & $\begin{array}{l}\text { Strive: } \\
\text { keep the } \\
\text { high note }\end{array}$ & Request & Pitch & $\begin{array}{l}\text { INDIRECT } \\
\text { ICONIC } \\
\text { Help } \\
\text { Melody }\end{array}$ \\
\hline $\begin{array}{l}4 \\
\text { Req.PS6 } \\
8.32\end{array}$ & $\begin{array}{l}\text { Maa- } \\
\text { [gni- } \\
\text { ficat] }\end{array}$ & $\begin{array}{l}\text { Shakes head } \\
+ \\
\text { clutches and } \\
\text { drops fists } \\
\text { down }\end{array}$ & $\begin{array}{l}\text { frowns } \\
+ \\
\text { squints eyes }\end{array}$ & I am angry & $\begin{array}{l}\text { Play very } \\
\text { loud }\end{array}$ & Request & Intensity & $\begin{array}{l}\text { INDIRECT } \\
\text { ICONIC } \\
\text { Help } \\
\text { Intensity }\end{array}$ \\
\hline $\begin{array}{l}5 \\
\text { Req.PS6 } \\
8.39\end{array}$ & $\begin{array}{l}\mathrm{Aa}^{-} \\
{[\mathrm{nima}]}\end{array}$ & $\begin{array}{l}\text { Head canting } \\
\text { rightward }\end{array}$ & $\begin{array}{l}\text { Raises } \\
\text { internal } \\
\text { parts of } \\
\text { eyebrows }\end{array}$ & $\begin{array}{l}\text { I feel a } \\
\text { poignant } \\
\text { feeling }\end{array}$ & $\begin{array}{l}\text { Play in a } \\
\text { poignant } \\
\text { way }\end{array}$ & $\begin{array}{l}\text { enacted } \\
\text { emotion } \\
\text { Meaning } \\
\text { oriented }\end{array}$ & $\begin{array}{l}\text { Expressi } \\
\text { vity }\end{array}$ & $\begin{array}{l}\text { GENERIC } \\
\text { CODIFIED }\end{array}$ \\
\hline $\begin{array}{l}6 \\
\text { Mag.PS8 } \\
1.09\end{array}$ & & & Closed eyes & $\begin{array}{l}\text { I am } \\
\text { concentrati } \\
\text { ng }\end{array}$ & & $\begin{array}{l}\text { Expressio } \\
n \text { of cogn- } \\
\text { itive state }\end{array}$ & $\begin{array}{l}\text { Concentr } \\
\text { ation }\end{array}$ & $\begin{array}{l}\text { GENERIC } \\
\text { CODIFIED }\end{array}$ \\
\hline $\begin{array}{l}7 \\
\text { Mag.PS8 } \\
4.27\end{array}$ & $\begin{array}{l}\text { (Strin } \\
\text { gs) }\end{array}$ & $\begin{array}{l}\text { Shakes head } \\
\text { and smiles }\end{array}$ & Closes eyes & $\begin{array}{l}\text { am } \\
\text { concentrati } \\
\text { ng }\end{array}$ & $\begin{array}{l}\text { I am } \\
\text { concentrati } \\
\text { ng on the } \\
\text { pleasure of } \\
\text { music }\end{array}$ & $\begin{array}{l}\text { Outcome } \\
\text { emotion } \\
\text { (to convey } \\
\text { it) }\end{array}$ & $\begin{array}{l}\text { MOTIVA } \\
\text { TING } \\
\text { (non- } \\
\text { musical) }\end{array}$ & $\begin{array}{l}\text { GENERIC } \\
\text { CODIFIED }\end{array}$ \\
\hline
\end{tabular}




\section{SEMIOTIC DEVICES IN THE CONDUCTOR'S GAZE}

The semiotic devices exploited in the lexicon of the conductor's gaze are the following:

1. Generic codified: a gaze item used in the conductor's lexicon with the very same meaning as in everyday communication. E.g., gazing at someone to request attention.

2. Specific codified: a gaze item used by the Conductor with a more specific meaning than in everyday interaction. E.g., gazing at someone not simply to request attention, but to ask for the attack.

3. Direct iconic: a gaze item that mimics aspects of music. Changes produced by body movements cause visual perceptions that, through modality transposition, evoke analogous changes in the auditory modality. E.g., raising a part of an eyebrow to evoke a raising of the pitch in singing.

4. Indirect iconic: gaze movements that by inference or by motor induction indirectly evoke the sound to produce. Such movements may be of three types: 4a. Expression of mental state: closing eyes, that in everyday language means "I am concentrating", in music performance may let you infer: "you concentrate, to prepare for the attack", or else "I concentrate to better feel the pleasure of the music you are playing".

4b. Expression of physical state: by strongly squeezing eyelids while saying "sforzatissimo", (= very effortful) the conductor imitates the expression of one who is making an effort, thus evoking the production of a "sforzato" sound.

4c. Expression of emotion: frowning eyebrows, by expressing anger, evokes the energy called for by anger, indicating strong intensity and hence a loud sound

\section{MEANINGS AND MUSICAL FUNCTIONS OF GAZE IN CONDUCTION}

The analysis of performance fragments by independent judges in terms of the above annotation scheme, taking the actual musical effect into account, showed that the same meanings are recurrently attributed to the same gaze items. This resulted in a lexicon of 17 gaze items [21], summarized in Table 2.

Table 2. The lexicon of the Conductor's gaze

\begin{tabular}{|c|c|c|c|c|}
\hline & $\begin{array}{c}2 \\
\text { GAZE ITEM }\end{array}$ & $\begin{array}{c}3 \\
\text { LITERAL MEANING }\end{array}$ & $\begin{array}{c}4 \\
\text { INDIRECT MEANING }\end{array}$ & $\begin{array}{c}5 \\
\text { TYPE }\end{array}$ \\
\hline 1 & Gazes at $X$ & Request for attention & Prepare to attack & Technical (attack) \\
\hline 2 & Gazes around at all musicians & $\begin{array}{lll}\text { Broadcast } & \text { request for } \\
\text { attention } & & \\
\end{array}$ & & Interactional \\
\hline 3 & Looks at all musicians & $\begin{array}{l}\text { Checking gaze. } \\
\text { (Non- communicative) }\end{array}$ & & Self-information \\
\hline 4 & $\begin{array}{l}\text { Raised eyebrows with oblique } \\
\text { gaze }\end{array}$ & Warning gaze & $\begin{array}{l}\text { I warn you about a } \\
\text { difficult passage }\end{array}$ & Interactional \\
\hline 5 & $\begin{array}{l}\text { Raised eyebrows with wide } \\
\text { open eyes }\end{array}$ & Emphasis & $\begin{array}{l}\text { I ask for higher } \\
\text { attention }\end{array}$ & Interactional \\
\hline 6 & $\begin{array}{l}\text { Eyebrow frown with wide } \\
\text { open eyes (+ extended index } \\
\text { finger) }\end{array}$ & Peremptory order & & Interactional \\
\hline 7 & Wide open eyes fixing $X$ & $\begin{array}{l}\text { Threating gaze } \\
\text { (to prevent similar } \\
\text { behaviour) }\end{array}$ & $\begin{array}{l}\text { I reproach you for your } \\
\text { mistake }\end{array}$ & Interactional \\
\hline 8 & Raised eyebrows (+nodding) & $\begin{array}{l}\text { Appreciation }+ \\
\text { approval }\end{array}$ & I praise you & Interactional \\
\hline 9 & $\begin{array}{l}\text { Continuous eyebrow frown } \\
\text { (+ rocking head) }\end{array}$ & Request to continue & & Technical \\
\hline 10 & Short single eyebrow raising & Higher note & & Technical \\
\hline 11 & $\begin{array}{l}\text { Raises eyebrows all along the } \\
\text { musical fragment (Fig. } 1 \text { a) }\end{array}$ & $\begin{array}{l}\text { Imitation of light } \\
\text { movement }\end{array}$ & Play/ sing soft & $\begin{array}{l}\text { Technical } \\
\text { (intensity) }\end{array}$ \\
\hline 12 & $\begin{array}{l}\text { Raises eyebrows } \\
\text { (+ head in the shoulders) }\end{array}$ & Caution gaze & Be accurate and precise & Attitude \\
\hline 13 & $\begin{array}{l}\text { internal parts of eyebrows } \\
\text { raised }\end{array}$ & Sad gaze & Play / sing in a sad way & Emotional \\
\hline 14 & Frown & Angry gaze & $\begin{array}{l}\text { Feel/express anger } \rightarrow \\
\text { play aloud }\end{array}$ & $\begin{array}{l}\text { Technical } \\
\text { (intensity) }\end{array}$ \\
\hline
\end{tabular}




\begin{tabular}{|l|l|l|l|l|}
\hline 15 & Squints eyes (Fig.1 b) & $\begin{array}{l}\text { Imitation of effortful } \\
\text { movement }\end{array}$ & Play/sing “sforzato" & $\begin{array}{l}\text { Technical } \\
\text { (intensity) }\end{array}$ \\
\hline 16 & Closed eyes (Fig.1 c) & Concentration & $\begin{array}{l}\text { I want (you) to enjoy } \\
\text { the pleasure of music }\end{array}$ & $\begin{array}{l}\text { Emotional } \\
\text { (Motivational non- } \\
\text { strategy: nog } \\
\text { musical) }\end{array}$ \\
\hline 17 & $\begin{array}{l}\text { Squeezed eyes }(+ \text { trunk } \\
\text { retracting backward) }\end{array}$ & Disgusted gaze & $\begin{array}{l}\text { Outcome emotion } \\
\rightarrow \text { Neg. feedback }\end{array}$ & Interactional \\
\hline
\end{tabular}

Col. 2 describes the considered gaze item, 3 its literal meaning, 4 a possible indirect meaning: e.g., at line 1, with item "gazes at musicians" the Conductor may simply call for attention (col.3), but this attention request is more typically codified with the indirect meaning "prepare to attack" (col.4).

Gaze items are classified (col.5) in different types: except for the checking gaze (line 3) that is non-communicative, those of order, emphasis to ask more attention, praise, reproach do not have a musical but an interactional function; gazes of attack, intensity (play/sing soft, loud or sforzato) and higher note convey technical indications, while an attitude/emotional category includes those asking for accuracy, concentration, or evoking some emotion.

Figure 1. Three items of gaze

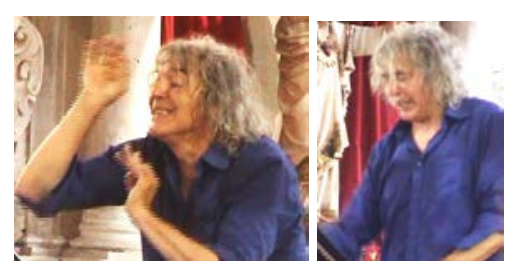

a: piano (11) b: sforzato (15)

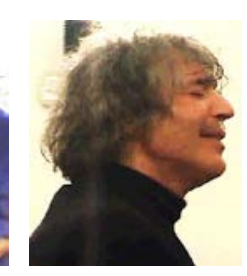

c. I concentrate on the pleasure of music

(16)

In subsequent observations on other Conductors, like Herbert von Karajan, Daniel Barenboim and Riccardo Muti, the same items of gaze were found to convey the same meanings as in Table 2 .

\section{THE LEXICON OF THE CONDUCTOR'S GAZE. A PERCEPTUAL STUDY}

After singling out the above list of gaze items in the above observational study, we run a perceptual study to test if such lexicon is in fact understood by musicians and laypeople.

Our research question was if people interpret these gaze items the same way as hypothesized above, and if these interpretations are the same by music experts and naifs, i.e., people with no experience in playing or singing in a music ensemble.

We tested 8 gaze items (see Table 3) out of the above 17 in a between-subjects study, where the independent variables were gaze items and the participants' level of expertise (expert/naif), while the dependent variable was the identity or degree of 2 similarity between the meaning we hypothesized for each signal and the participant's interpretation.

\subsection{Materials and method}

To build our stimuli, we cut 8 brief fragments (duration 1 to 13 seconds, medium length 3,1") with the selected gaze items in videos of four Conductors: Karajan, Barenboim, Muti, and Anniballi (Table 3). For control goals, we added two "neutral gaze" videos.

Table 3. Gaze stimuli

\begin{tabular}{|c|c|c|c|c|}
\hline & SIGNAL & MEANING & TYPE & COND \\
\hline 1 & closed eyes & $\begin{array}{l}\text { I am } \\
\text { concentrated }\end{array}$ & Attit. & vKar \\
\hline 2 & eyebrow frowning & play loud & Techn & Ann \\
\hline 3 & $\begin{array}{lr}\text { raised } & \text { eyebrows } \\
\text { along } & \text { whole } \\
\text { fragment } & \\
\end{array}$ & Play soft & Techn & Ann \\
\hline 4 & $\begin{array}{l}\text { Short eyebrow } \\
\text { raising }\end{array}$ & High note & Techn & Ann \\
\hline 5 & Squeezed eyes & Play sforzato & Techn & vKar \\
\hline 6 & $\begin{array}{l}\text { Internal parts of } \\
\text { eyebrows raised }\end{array}$ & Play poignant & Emot. & Bar \\
\hline 7 & $\begin{array}{l}\text { Wide open eyes } \\
\text { fixing musicians }\end{array}$ & $\begin{array}{l}\text { I } \quad \text { reproach } \\
\text { you: } \text { mistake }\end{array}$ & $\begin{array}{l}\text { Intera } \\
\text { ct }\end{array}$ & Ann \\
\hline 8 & $\begin{array}{l}\text { Gaze at musicians } \\
\text { with an eyebrow } \\
\text { flash }\end{array}$ & Start now & Techn & Mut \\
\hline
\end{tabular}

Our aim was to check whether participants could figure out the meaning of each gaze even without any hint; but if this was not the case, we wanted them to provide some answer anyway. So we constructed 10 different questionnaires, each containing only two gaze stimuli: the first with an open question; the second with a closed question asking participants to assess how plausible, on a 5-points Likert scale (1=not at all, 5=very plausible), was each of 13 interpretations, among which the one hypothesized by our previous observational study. The 13 alternatives were: play soft, in a passionate way, loud, with anger, in a more accurate way, start exactly now, play in a poignant way, play progressively louder and louder, here there is 
a high note, play sforzato, I am in concentration, play progressively softer and softer, I reproach you.

Before the open question, the questionnaire investigated participants' musical expertise: whether they would play some instrument, or sing or play in a music ensemble, of what kind and of how many musicians, if and how frequently they attended concerts (on a 5-points Likert scale). The open question asked to view the video without audio, to tell what did the conductor mean by his face, and what made them think so. Then again, between the open and the closed question, other questions on musical instruments and voice timbers tested participant's musical expertise, while also distracting and avoiding habituation between the open and closed question.

To prevent a within-subject effect, each questionnaire only contained two stimuli: the first with the open, the other with the closed question, with the ten videos $(8$ crucial and 2 control stimuli) randomly distributed in 10 questionnaires.

The questionnaires were submitted to 177 participants, 64 males and 113 females, mean age 22,3. Closed questions were subject to quantitative analysis and open questions to qualitative analysis.

\subsection{Results}

Can participants distinguish the meanings conveyed by the Conductor? Which meanings? To what extent?

Are there differences between musicians and laypeople in stimulus interpretation?

\subsubsection{Stimuli comprehensibility. Closed questions}

Before testing the comprehensibility of stimuli, we run an ANOVA among the alternatives of the closed answer (Table 4): four of them - louder and louder (crescendo), high note, sforzato, concentration - were excluded from the analysis, not reaching the significance level.

Concerning stimuli comprehensibility, for ease of analysis we distinguished them into three categories: a. general technical indications ("high note", "attack"); b. intensity (concerning musical dynamics: "play soft" and "play loud)"; and c. attitude/emotion indications ("play poignantly", "concentration").

While the stimuli of the last category, attitude/emotion, did not reach the significance level $(p>, 30)$, others resulted highly comprehensible for the participants within the assigned category. Within "technical" indications the most comprehensible was "attack" ( $\mathrm{M}_{\text {attack }}=3,42$ Mhigh note $=2,00 \mathrm{p}=$ ,002); "intensity" elicited excellent discrimination between the two opposite meanings "soft" $\left(\mathrm{M}_{\text {soft }}=3,30 \mathrm{M}_{\text {loud }}=1,35 \mathrm{p}<, 001\right)$ and "loud" $\left(\mathrm{M}_{\text {soft }}=1,26 \mathrm{M}_{\text {loud }}=3,68 \mathrm{p}<, 001\right)$.

For cases of mismatch - e.g., "forte" interpreted as "with anger" - we stress that, as shown in Sect. 4, affective and intensity indications are clearly connected: conductors indicate to play louder by expressions of anger or euphoria, since they, by making appeal to the energy of these emotions, help musicians to play "forte" (loud) [17-19]. In this regard, we successfully ran a correlational analysis between the questionnaire items (Table 5), showing that interpretations of intensity highly correlate with attitude/emotion indications.

Table 4. Anova

\begin{tabular}{|l|l|r|}
\hline \multicolumn{1}{|c|}{ ITEM } & \multicolumn{1}{c|}{ F } & \multicolumn{1}{c|}{ SIG. } \\
\hline play soft & 9,247 & $<, 001$ \\
\hline play in a passionate way & 11,00 & $<, 001$ \\
& 3 & \\
\hline play loud & 28,40 & $<, 001$ \\
& 2 & \\
\hline play with anger & 9,062 & $<, 001$ \\
\hline play in a more accurate way & 3,744 & $<, 001$ \\
\hline start exactly now & 4,077 & $<, 001$ \\
\hline play in a poignant way & 4,023 & $<, 001$ \\
\hline play progressively louder and louder & 1,768 &, 078 \\
\hline here there is a high note & 1,473 &, 162 \\
\hline play sforzato & 1,394 &, 194 \\
\hline I am in concentration & 1,463 &, 166 \\
\hline play progressively softer and softer & 3,137 &, 002 \\
\hline I reproach you: mistake & 2,677 &, 006 \\
\hline
\end{tabular}

Table 5. Correlation between intensity and affective stimuli

\begin{tabular}{|c|c|c|c|}
\hline \#1 & \#2 & P & P \\
\hline Play loud & Play with anger &, 604 & $<, 001$ \\
\hline Play loud & $\begin{array}{c}\text { Play in a poignant } \\
\text { way }\end{array}$ &, 517 & $<, 001$ \\
\hline Play soft & $\begin{array}{c}\text { Play in an accurate } \\
\text { way }\end{array}$ &, 293 & $<, 001$ \\
\hline
\end{tabular}

\subsubsection{Stimuli comprehensibility. Open questions}

For the analysis of open questions, each answer was classified in the category "technical", "intensity" or "attitude/emotion" and, by matching it to the category of the stimulus, it was attributed a four-step score (0 to 3). While answers to the two control items spread across all categories, the mean scores of those about the experimental stimuli are not high, ranging from 0,51 for "poignant" to 1,81 for "piano". For "high note", only 4 participants out of 23 interpret the stimulus as "tone raising", while many others mention emotions like "passion", "involvement", "enthusiasm", "light-heartedness". Yet, some answers confirm the relationship between the categories "intensity" and "attitude/emotion": the stimulus "forte" is interpreted only by one participant as "He communicates a lot of intensity", but by others as rimprovera qualcuno (he reproaches 
someone), rabbia (anger), violenza (violence), rigore (strictness), grinta (grit), foga (heat): all these words allude to high arousal movements, like those performed to play or sing forte. This confirms our hypothesis on the semiotic device of indirect iconicity 4c. above: emotion expression generally implies an intensity indication.

\subsubsection{Naïfs vs. "Experts"}

With regard to the differences in meaning recognition between naifs and experts, four different criteria could be adopted to create a sub-sample of experts within our general sample: to consider experts

- $\quad$ only the participants who declared to be members of a band, an orchestra or a choir.

- participants in the first condition + those who declared to play an instrument.

- participants in the first and second condition + the ones who declared to be habitual spectators of many concerts (Likert scale ratings from 4 to 5 ).

- $\quad$ only the participants who declared to be habitual spectators of many concerts.

In none of these cases did the ANOVA reach the significance level. It seems that there are no significant differences between laypeople and musicians in the recognition of gaze items for music conduction.

\section{DISCUSSION AND CONCLUSION}

The goal of our work was to investigate the lexicon of the conductor's gaze. Through an observational study on a corpus of conduction in rehearsal and concert we singled out 17 items of gaze conveying specific meanings: interactional, such as praise, warning or reproach; technical, like indications of intensity, melody, attack; and attitude/emotion, like concentration, passion or sadness. Then we selected 8 of these gaze items to test their comprehension in a perception test.

We found that especially some technical items, namely those of attack, high note, piano and forte, reach a fair level of comprehension, while those of attitude and emotion tend to be more frequently interpreted as indirect technical indications.

Further, we did not find any significant difference in comprehensibility of gaze items between naï and expert subjects. This reinforces the hypothesis of a parallel work on the conductor's intensity gestures, that also finds a continuity between those for musical indications and everyday gestures [18]: to put it briefly, the former do not constitute a specific jargon, because they exploit the same mechanisms for gestural/signal creation as plain language, such as metaphor and metonymy, conveying the right meanings through generic codified, emotional, and iconic expressions. We can thus break the spell of the incomprehensibility of the conductor's language, often seen as obscure and understandable by the inner circle of the well-trained musicians only.

But if the idea of gaze in music performance as a specialized jargon is unwarranted by our work, the fair level of recognizability of some gaze items tells us that gaze is a language in music performance as well as in everyday life.

Actually, this is only a first study in such domain, and its results are moderately encouraging. Some limitations in our perceptual study were that the videos shown to participants did not select the gaze display only, but sometimes included the conductor's general movement, namely gesture, that may have helped understand the meaning. Future work will be conducted by singling out the region of eyes, eyebrows and eyelids only, either by cutting the real videos or by simulating the gaze items in Virtual Agents, so as to more precisely capture what specific movements of eye-gaze convey the meanings of musical conduction. These studies will make it possible to construct believable ECAs and robot conductors

\section{ACKNOWLEDGMENTS}

The work is partially funded by the Italian National Project PRIN "Cultural Heritage Resources Orienting Multimodal Experiences (CHROME)” n. 2015WXBPYKCHROME. We are indebted to Mo Alessandro Anniballi for letting us so generously record and analyse his conduction.

\section{REFERENCES}

[1] M. Puig Rodríguez-Escalona \& A. Fornés. "Mirar de reojo y fijar la mirada en los textos latinos", Cuadernos de Filología Clásica. Estudios Latinos 31/2, 2011, 213-234.

[2] M.Argyle \& M. Cook (1976). Gaze and mutual gaze. Cambridge: Cambridge University Press.

[3] R. Thompson, K. Emmorey, R. Kluender (2009) The relationship between eye gaze and verb agreement in American Sign Language: An eye-tracking study Natural Language and Linguistic Theory. 24: 571-604.

[4] P. Ekman (1979). About brows: Emotional and conversational signals. Human ethology, 163-202.

[5] K. Jokinen, H. Furukawa, M. Nishida, \& S. Yamamoto (2013). Gaze and turn-taking behavior in casual conversational interactions. ACM Trans. Interact. Intell. Syst.

[6] Vincze, L., Poggi, I. (2011) Communicative Functions of Eye Closing Behaviours. In Esposito, A., Vinciarelli, A., Vicsi, C.,Pelachaud, C., Nijholt., A. (Eds). Proceedings of the Conference "Analysis of Verbal and Nonverbal Communication and Enactment: The Processing Issues". pp. 401-416.

[7] I. Poggi (2011) "Music and leadership: the Choir Conductor's multimodal communication”. In M. Ichino \& G. Stam (Eds.), Integrating Gestures. The interdisciplinary nature of gestures. Amsterdam: John Benjamins, pp.341-353.

[8] I. Poggi (2007): Mind, hands, face and body. A goal and belief view of multimodal communication. Berlin: Weidler 2007.

[9] M. Rudolf (1995). The Grammar of Conducting: A Comprehensive Guide to Baton Technique and Interpretation. London: Cengage Learning.

[10] E. Greene (1997) The Modern Conductor: a College Text on Conducting Based on the Technical Principles of Nicolai Malko as set forth in his The Conductor and his Baton. Englewood Cliffs, N.J.: Prentice-Hall.

[11] H. Saito (1988) The Saito Conducting Method. Trans. by Fumihiko Torigai. Tokyo: Min-on Concert Association and Ongaku Tomo Sha Corp.

[12] P. Boyes Braem, \& T. Braem (2004), "Expressive gestures used by classical orchestra Conductors". In C. Müller \& R. Posner (eds.). The semantics and pragmatics of everyday gestures. Weidler: Berlin, pp.127-143.

[13] D. Veronesi (2009) “'The guy directing traffic': gestures in conducted improvised music between metaphor and metonymy", RAaM Workshop 2009 Metaphor, Metonymy and Multimodality, Amsterdam June 5, 2009.

[14] P. Bos, D. Reidsma, Z. Ruttkay and A. Nijholt (2006) Interacting with a virtual Conductor. In Harper, R., Rauterberg, M., and Combetto, M., Eds. Proc. of 5th International Conference on Entertainment 
Computing, Cambridge, UK (September 2006). Berlin: Springer Verlag pp. 25-30

[15] G. Johannsen \& T.M. Nakra. Conductors' gestures and their mapping to sound synthesis. In R. I. Godøy and M. Leman (Eds.) (2010). Musical gestures: sound, movement, and meaning. New York and London: Routledge

[16] I. Poggi (2002): "The lexicon of the Conductor's face". In P.McKevitt, S. O' Nuallàin, C. Mulvihill (Eds.) Language,Vision, and Music. Selected papers from the 8th International Workshop on the Cognitive Science of Natural Language Processing, Galway, 1999. Amsterdam: John Benjamins, pp.271-284

[17] I. Poggi (2017). Signals of intensification and attenuation in orchestra and choir conduction. Normas, 7(1), 33-47

[18] I. Poggi \& A. Ansani (2017). Forte, piano, crescendo, diminuendo: Gestures of intensity in orchestra and choir conduction. In Proceedings of the 4th European and 7th Nordic Symposium on Multimodal Communication (MMSYM 2016), Copenhagen, 29-30 September 2016 (No. 141, pp. 111-119). Linköping University Electronic Press

[19] I. Poggi (2006). "Body and mind in the Pianist's performance". In M.Baroni, M.R.Addessi, R.Caterina, \& M.Costa (Eds.), Proceedings of the 9th International Conference on Music Perception and Cognition, ICMPC, Bologna, 22- 26 August, 2006, pp.1044-1051.

[20] I. Poggi (2018). Lo sguardo del maestro. In C. Corradi (a cura di) Cultura popolare, religione diffusa, analisi qualitativa: un sociologo italiano a cavallo tra due secoli. Studi in onore di Roberto Cipriani. Perugia: Morlacchi, pp.233-252 